\begin{abstract}
Shapsugova M.D.
Institute of State and Law RAS, Business and Corporate Law Department, Senior Research Fellow, Candidate of Legal Sciences
\end{abstract}

\title{
PRIVATE FINANCE IN THE LEGAL SYSTEM
}

\begin{abstract}
The transition to market relations increases the relevance of the study of decentralized finance. As P. A. Levchaev rightly remarked, due to the historical specifics, the peculiarity of Russia's financial science was a detailed study of the state finances of the planned economy of socialism. In contrast, the functioning of the finances of business entities often remained insufficiently studied. So, the subject of financial law is a state and municipal finance. Private decentralized finance is not studied by legal financial science, which gives rise to a fragmentary regulation of these relations by civil law.
\end{abstract}

Keywords: commercial law, private finance, business, decentralized finance

Financial relations are a kind of economic relations characteristic of developed societies. There are distribution and redistributive financial relations. The legal distribution relations are relative of primary distribution, which can be carried out either in cash or in kind. A form of expression of distributive relations in the organization is the distribution of profits for the reproduction, investment, consumption (including dividends). Financial redistribution relations (relations of secondary distribution) are manifested primarily in the organization's financial relations with the budget system.

The concept of "economic relations" is broader than the concept of financial relations (they are correlated as a whole and part). Therefore, all financial relations are economical, but not all economic relations can be considered financial. Economic relations are transformed into financial ones only when a public interest arises, carried out by a powerful entity that implements its financial policy, and monetary relations arise that are accompanied by cash accounting procedures $[1,25]$. The content of financial relations depends on the content of economic relations, reflecting the degree of development of productive forces in the country. We observe the interdependence and interdependence between the content of economic and financial relations.

The formation of financial relations occurs when economic relations reach a certain level of development. Financial relations are commodity-money and arise as redistributive, firstly, in the presence of developed commodity- money exchange, and secondly, with the emergence of certain separate trust funds of funds that imply directly covering government spending related to the implementation of public state interest $[1,23]$.

With the development of statehood, financial and legal regulation is being strengthened. Therefore, financial relations are characteristic of a higher stage of development of society. Financial relations, is a type of economic relations, have specific features :

Represent a monetary relationship;

Reflect redistributive relations;

arise about the formation, distribution, and use of financial resources, as well as financial planning and control.

According to E. M. Ashmarina, the content of financial relations at one or another historical stage of social development is determined, firstly, by objective economic relations characterizing the 
degree of development of productive forces in the country, and, secondly, by the state's financial policy, embodied in a law that directly affects dynamics of production relations [1, 25-26].

They are distributed on the view that the content of finances - is the economic and legal relationship. In form, finances are cash funds. However, finances do not always have fund form, especially in private finance, including in finance commercial organizations. For example, the distribution of profits does not have a fund form.

The paradigm of financial law, widespread both in Russia and abroad, is based on a specific foundation called by N. M. Kazantsev "the state-real dogma of finance". According to this dogma, money is proprietary, public finance is public property formed by money funds, and financial law is a regulator of financial relations as legal relations arising from actions and operations carried out with money. Moreover, the consideration of finances as objects of regulation of cash funds dominates the analysis of such funds as legal entities, and the problematic issue of the public-law or private- law nature of these individuals is decided in favor of private law [2]. The limitation of the state-owned dogma of finance, according to N. M. Kazantsev, is manifested in the fact that, on its basis, such regulation of financial relations cannot be ensured that will be sufficiently complete to prevent the onset of financial crises [2].

In the structure of financial activity, financial relations are one of the forms in which it is carried out, along with behavior, actions, operations, and object. In the educational literature, it is noted that economic relations act as an object of financial activity, or rather, property relations, and as a result, income, accumulation, etc. business entities and individuals, as well as own resources of the state and municipal entities [3, 34].

Financial activities are carried out regarding financial resources and cash funds. In the implementation of financial activities, relations are formed that take the form of legal relations. Financial resources, monetary funds, and the behavior of subjects of financial activity can be considered as objects of financial, legal relations, and (or) secondary objects of financial activity.

Consider the relationship between the concepts of "relations in the field of financial activity", "financial relations", "objects of financial activity".

Relations in the field of financial activity are traditionally referred to as financial relations. However, it is believed that the relations arising in the implementation of financial activities are complex, i.e., include financial law, civil law, and other relations-for example, A. I. Khudyakov writes: "At the most superficial examination it turns out that the state is creating, distributing and using its money funds not only based on economic-financial, but also other types of economic relations. Thus, budgeting can be carried out, for example, by way of obtaining income from leasing state property. The resulting relations from an economic point of view are commodity-money. The use of state monetary funds, where the state, acting as a buyer of goods (works, services) paid for from the funds of the corresponding monetary fund (for example, the budget), is also carried out within the framework of commodity-money relations. Moreover, in both cases, relations are regulated by civil law, i.e., from a legal point of view, they are civil" [10, 4].

It seems, however, that this view is inaccurate and A. I. Khudyakov, contrary to the tenets of economic theory, considers financial relations to have no relation to commodity-money. Meanwhile, financial relations arise and function only in the sphere of commodity-money relations, which are a necessity for the existence of financial relations. Besides, the process of forming sources of financial resources should not be confused with the financial resources themselves, regarding the income cited by A.I. Khudyakov, as an example, can also object that the process of obtaining these incomes is not studied by financial law. The source of budget revenue is considered as a source of financial resources for the budget. Thus, getting into the treasury, income acquires a special financial and 
legal regime different from the legal regime of the process of its receipt and, accordingly, civil law and other regulation methods.

It is difficult to agree with the assertion that relations on the use of state monetary funds, when the state acts as a buyer of goods (works, services) paid for from the funds of the corresponding monetary fund (for example, the budget), are exclusively civil law, in most cases, they act as complex and are also regulated by administrative law.

Objectionable is the classification of financial relations in the field of civil law solely by the regulatory method since financial and legal relations differ from civil law in essence [5, 70-73]. This also applies to the issue of financial relations in the finances of organizations, or, as they are commonly called "decentralized private finances".

It disagrees with the interpretation of the subject area of financial law A.I. Khudyakov, however, should agree with his proposal to distinguish between the concepts of "relations in the field of financial activity" and "financial relations". A. Khudyakov also refers to relations in the field of financial activity, in addition to financial, as civil law and other relations that cannot be the subject of financial law, unless it is assumed that this branch of law is independent and not complex [4]. Consequently, the concept of relations in the field of financial activity is broader than the concept of financial relations and is interbranch (complex).

Thus, in our opinion, relations in the field of financial activity include two groups:

1. financial relations;

2. related civil, corporate, entrepreneurial, labor, administrative, and other law relations.

The objects of financial activity are relations in the field of financial activity. Based on the previous, the object of financial activity should include primarily financial relations and the accompanying civil law, administrative, and other relations. In this paper, we dwell on the study of financial relations in an organization as a variety of financial relations, an object, and a form of financial activity.

In our view, prevailing in the science of financial law, understanding of the financial relationship is narrow. Here are some examples.

In the opinion of $\mathrm{Yu}$. A. Krokhina, financial, legal relations are economical and legal social relations regulated by financial law, having an authority-property character, and expressing public interests. Peculiarities of financial relations are [6, 92-93]:

They arise and function in the process of the planned accumulation, distribution, and use of state and municipal monetary funds.

They are a kind of property relations that are public. It should be noted that during the implementation of financial activities, procedural (organizational) legal relations arise, but they are of a secondary (derivative) nature because they provide the movement of financial resources of the state and municipalities.

Financial legal relations require the obligatory participation of the state or municipality in the person of competent authorities or officials.

Most financial legal relations are subordinate in nature and are built according to the "power submission" scheme.

The legal liability of an unscrupulous participant in a financial legal relationship does not arise before the other side, as in most other branches of law, but directly before the state.

In the above signs of financial law, relations really have a place to be. However, they are peculiar only to public financial relations. Moreover, the state acts in these respects as a party. Therefore, we believe it is inaccurate to say that responsibility comes before the state and not before the party. Such a situation characterizes the state's dual nature as a subject of financial relations: on the one hand, it regulates and organizes the relationship, and on the other, it is its direct participant. 
The same thing, in one form or another, is happening in other branches of law, such as civil law. That is why this feature can hardly be considered as qualifying a financial legal relationship.

According to another approach, financial relations are public relations regulated by the norms of financial law, the participants of which act as carriers of legal rights and obligations, implementing the requirements for the formation, distribution and use of state, municipal and other public monetary funds contained in these norms [7, 75].

In the textbook edited by M.V. Karaseva, the following characteristics of the financial legal relationship are given, due to the specifics of the subject and method of financial and legal regulation $[8,129-131]$ :

1. It arises and develops exclusively in the field of financial activity of the state and municipalities.

2. It serves as a form of realization of public interests, in connection with which it should be considered as a public law relation.

3. In essence, it is an economic relation.

4. It has a property character. In the financial legal relations, property (cash) and cashless assets act as property benefits.

5. It is a power relation.

The property-property nature of the financial legal relationship serves as a criterion for delimiting it from civil law relations $[8,131]$.

As you can see, these definitions have a lot in common: financial relations arise in the sphere of financial activity of the state and municipalities, have power-property and public character.

It is believed that in characterizing a financial legal relationship, it is worth emphasizing its understanding not as a power relationship, but as a managerial relationship, built mainly on the principle of differentiating rights, duties, competencies and responsibilities.

The understanding of financial legal relations prevailing in financial and legal science, in our opinion, is caused by a narrow understanding of financial activity and the identification of the concepts of "financial activity" and "financial activity of the state and municipalities". Objectively existing financial activities of an organization are not included in the financial and legal concept of financial activity, which entails a narrowing of the concept of "financial legal relationship", which, by the above concepts, arises exclusively in the field of financial activity of the state and municipalities, is of a power-property, public nature. Outside of such an understanding of financial legal relations, objectively existing financial legal relations in the field of decentralized finance remain.

Financial equality in the organization and does not meet the specificity. Nevertheless, does it start that it is not financial and legal? Perhaps, no.

The fact that financial relations in organizations do not fit into the subject of financial law in its modern sense cannot be doubted, but is it right? Why is the relationship having e financial nature should be considered as civil law, rather than the financial and legal?

The finances of organizations exist; they are part of the financial system; their denial in financial law does not change the objective situation.

Therefore, it seems necessary to adjust the definition of financial legal relations taking into account financial legal relations arising in the finances of organizations. In our opinion, the concept of financial legal relations is broader than the concept of public financial legal relations and includes, in addition to public, private financial legal relations.

According to the criterion of areas of financial activity, financial relations can be divided into two types: 
- public financial relations arising in the field of financial activities of the state and municipalities;

- private financial relations are arising in the field of financial activities of organizations and individuals.

It is difficult to make a clear distinction between public financial legal relations and private relations, because, at the junction of these relations, there is a complex of mutually penetrating private-public elements of relations between both groups. This border is very mobile. The total amount of public and private regulation in a particular financial relationship depends on the group of financial relationships and is expressed in the financial resources' legal regime, determined by the scope of each type of financial activity.

The existing in the science of financial law and the above signs of financial legal relations are signs of public financial relations. The distinction between public and private financial relations will require further identification of signs of private financial legal relations, as well as typical signs of financial legal relations of both of their groups (both private and public financial legal relations) and a new understanding of financial legal relations in general. However, it should be noted that to hold the distinction of methods of regulation becomes more difficult. The relations in their groups are exposed to both mandatory and discretionary methods of regulation. The question is in the extent of the presence of particular method in the dominant (as the public in private and private in public).

Since we proceed from the unity and integrity of financial relations, we believe that the legal regulation of financial relations will be based on a single coordination method, including a system of sub-methods: mandatory requirements, coordination (autonomy of will), and recommendations.

Financial relations may arise between equal entities. However, this problem requires special consideration.

We suggest understanding the financial legal relations as the rules of law regulating the social relations on the formation, distribution, and use of financial resources.

Financial legal relations of an organization can exist simultaneously in three planes:

1) vertically - in relations with regulatory and control bodies;

2) horizontally - in relations with other business entities;

3 ) as on-farm relations - financial relations within the organization.

Therefore, in our opinion, financial legal relations have a complex character: relations of subordination, and relations based on equality.

Consider the structure of the financial relationship in the organization. In the structure of legal relations, it is customary to distinguish subjects, objects, content. The subject of relations in the field of financial activity has a complicated interbranch status. Its industry statuses are interconnected and interdependent.

A prerequisite for acting as a subject of a financial legal relationship is a financial personality. However, complexity arises here too. No special general features of the subject of financial law are highlighted in the specialized literature. Usually, when characterizing the subjects of financial law, they are listed, which does not entirely reflect their specifics. Therefore, the industry affiliation of the subject of financial law cannot be determined in isolation from his rights and obligations in a financial relationship or his intersectoral legal status and financial legal capacity.

Legal personality in private and public financial relations has its characteristics. First of all, the circle of subjects of financial relations in private and public relations will be different. Common features of legal personality will be determined by the unity of the scope of financial activity.

Financial relations in the organization can be divided into external and internal (internal). The subjects of financial relationships in the organization $\mathrm{s}$ are the organizations themselves and in the farm financial ratios $\mathrm{x}$ and their subdivisions and organs. 
The organization itself, as the subject of tax relations, foreign exchange control relations, relations with banking and insurance organizations, obviously has such a property as a financial personality. Difficulties arise in determining the financial personality of individual units of the organization. Following the established tradition, e e cannot be called financial and legal. The problem with the legal regulation of intraeconomic relations is associated with the regulation of accounting and its industry affiliation and requires independent consideration. According to the established tradition, intraeconomic relations are not included in the subject of financial law. The issue of the concept, composition, legal status of separate divisions is debatable and requires particular research.

As L. N. Dreval notes, "in the history of the development of financial legislation there was a period when the subjects of financial law - taxpayers, by the provisions of the Federal Law "On Property Tax of Enterprises and Organizations" (1991), correctly recognized branches and other similar units having a separate balance and settlement account ". However, for financial law, the allocation of collective entities in this interpretation as an independent species does not seem to L. N. Dreval $[9,94]$.

The tax legal personality is only part of the legal entity's financial legal personality (its units are partially legal in tax law). The legal personality of organizations in financial relations in the sphere of financial activity of organizations will include constitutional and legal civil law, financial and legal (including tax and accounting), administrative and legal branch legal personality.

N.I. Khimicheva believes that in order to enter into financial legal relations, enterprises and other commercial organizations, as collective subjects of financial law, should have legal independence, have their financial plan, however, the law provides that branches and other separate divisions of enterprises can fulfill the duties of the latter, in particular payment of taxes at the place of location (Article 19 of the Tax Code) [7, 86]. As follows from Art. 19 of the Tax Code of the Russian Federation, organizations and individuals, are recognized as taxpayers and payers of fees that are obligated under this Code to pay taxes and (or) fees, respectively; in the manner prescribed by the Tax Code of the Russian Federation, branches and other separate divisions of Russian organizations fulfill the obligations of these organizations to pay taxes and fees at the location of these branches and other separate divisions.

Per Art. 11 of the Tax Code of the Russian Federation, a separate subdivision of an organization is any geographically isolated subdivision from it, at the location of which stationary workplaces are equipped. Recognition of a separate division of an organization is carried out regardless of whether its creation is reflected in the constituent or other organizational and administrative documents of the organization and from the powers vested in it. At the same time, a workplace is considered stationary if it is created for more than one month.

Assuming that in external financial relations, primarily tax, branches, and representative offices are not subjects of financial legal relations, we believe that they have some aspects of a financial legal personality. In particular, they fulfill the obligation to pay mandatory payments of Russian organizations.

A particular specificity distinguishes Intraeconomic relations: in intraeconomic relations, organizational units are full-fledged entities.

Legal personality presupposes the existence of legal capacity and legal capacity. Any organization has financial legal capacity since its inception. Financial solvency depends on the occurrence of certain legal facts or the presence of actual compositions, depending on the type of financial relationship in the organization's financial sphere. For instance:

- in tax relations - the presence of all elements of the tax ; 
- in financial relation on dividend payout - a decision of the General Meeting, the availability of stocks and shares, the absence of circumstances that restrict the payment of dividends according to the law;

- during payroll - the presence of an employment contract, an order for employment, accounting documents.

\section{Resferences}

1. Ashmarina E. M. Financial and legal aspects of accounting systems of the Russian Federation: Dis .... Dr. jur . sciences . - M., 2005.

2. Kazantsev N. M. The principle of jurisdiction in the development of the dogma of financial law // Journal of Russian law, 2009.№ 5. Pp 3-14.

3. Financial Law // Under the editorship. M.V. Karasev. - M .: Lawyer, 2007.

4. Khudyakov A. I. Discussion questions of the subject of financial law // Yurist, 2009. Pp 2-8.

5. Shapsugova M. D. On the conceptual integrity of financial relations // North Caucasian Legal Bulletin . 2009 . № 3.

6. Yu. A. Krokhina. The financial law of Russia . - M.: Norma, 2008.

7. Financial Law / Ed. N.I. Khimicheva. - M.: Norma, 2008.

8. Financial Law / Ed. M.V. Karaseva. - M.: Yurait, 2015.

9. Dreval L.N. Subjects of Russian financial law / Ed. Doctor of Law, Prof. E. Yu. Gracheva. - M., 2008. 